\title{
Товбаз Е.Г.
}

\section{Приёмы ЛитРПГ как средство активизации познавательного интереса студентов вуза в процессе изучения социально-гуманитарных дисциплин}

Комсомольский-на-Амуре государственный университет (Россия, Комсомольск-на-Амуре)

doi: $10.18411 /$ sr-10-08-2020-27

idsp: sciencerussia-10-08-2020-27

\section{Аннотация}

Данная статья посвящена рассмотрению целесообразности использования приёмов литературного РПГ в практике обучения студентов вуза. В статье характеризуются основные элементы ЛитРПГ, применяемые в процессе изучения социально-гуманитарных дисциплин: квестовость, погружение, наличие роли персонажа в обучающей игровой вселенной, основанной на реалиях преподаваемой дисциплины.

Ключевые слова: познавательная активность, обучающая игра, текстовая информация, литературное РПГ, современные студенты, информационное пространство.

\section{Abstract}

The given article deals with the practical purpose of using LitRPG techniques in teaching university students. The article characterizes essential LitRPG elements applied in social and human disciplines educational process: quest solving, immersion, character's role in an educational game universe, based on realia of the aimed discipline.

Keywords: cognitive activity, educational game, text information, Literary Role Playing Game, modern students, information field.

На сегодняшний день проблема разработки и внедрения в педагогическую практику более совершенной методики обучения, обеспечивающей повышение качества учебной работы, активизацию познавательной деятельности студентов, развитие их умственных способностей, не утратило своей актуальности.

В процессе обучения студентам приходится усваивать большой объём текстовой информации. Такая информация может быть различной по степени трудности и усваиваться соответственно по-разному в зависимости от ряда факторов. В том числе, и познавательных особенностей студентов.

Изучив работы, посвящённые исследованиям особенностей познавательной деятельности и мотивации современных студентов, мы пришли к выводу о целесообразности разработки таких методов и приёмов обучения, которые учитывали бы данные особенности и опирались на них, а также способствовали наиболее успешной реализации интеллектуального потенциала обучающихся. Наряду с этим мы преследовали цель активизации творческой деятельности в ходе освоения учебного материала, как неотъемлемого условия развития личности.

В основу нашего подхода легли по крайней мере три парадигмы:

1. Необходимость внедрения в области современного образования инноваций, обусловленных развитием нового информационного пространства и изменением социальных потребностей общества.

2. Интерактивность - как условие повышения эффективности обучения студентов.

3. Учёт психологических особенностей, в частности характеристик мыслительной деятельности и познавательных процессов современных студентов. 
На последнем пункте остановимся чуть подробнее, чтобы акцентировать внимание на основных причинах, из-за которых в настоящее время возникают трудности в обучении у студентов-первокурсников: «преобладание «клипового» мышления; непонимание сложности представленного материала, проблемы с усвоением больших объемов информации; быстрая отвлекаемость из-за «скучности» изложения или отсутствия игрового момента в обучении; неразвитые коммуникативные навыки; неумение самостоятельно находить решения и организовать свое время для занятий, распределять временные и психические ресурсы в процессе обучения».

Однако существуют и неоспоримые преимущества современных студентов, которые необходимо учитывать в процессе обучения: «ярко выраженный индивидуализм и интеллектуальный потенциал; с легкостью ориентируются в мировых информационных ресурсах и быстро находят нужную информацию».

Проанализировав представленные выше результаты исследований, мы пришли к выводу, что приёмы ЛитРПГ, применяемые в ходе обучения способны преодолеть существующие трудности в силу конструктивного использования лежащих в их основе причин, а также главных преимуществ, посредством преобразования основных недостатков в достоинства. Например, формирование и стимулирование способности самостоятельно находить решения, при выполнении задания, основанного на выборе, от которого зависит дальнейшее продвижение на следующий уровень. Для того, чтобы прояснить вышесказанное обратимся непосредственно к тому, что представляет собой ЛитРПГ как жанр и методический приём.

«ЛитРПГ (литературное РПГ) - относительно новый жанр фантастической литературы, основанный на субкультуре популярных ролевых компьютерных игр. Данный жанр описывает как реальность, так и мир компьютерных ролевых игр, вымышленных или реально существующих. Книги в жанре ЛитРПГ характеризуются тем, что по ходу сюжета используются вставки текстовых сообщений об игре или расширении имеющихся у персонажей природных и иных характеристик. Кроме того, такие произведения относят к фантастическому «попаданчеству»».

Таким образом, с нашей точки зрения целесообразно использовать в процессе изучения учебного материала некоторые приёмы, характерные для игровой механики ЛитРПГ:

1 Наличие обучающей (интерактивной) игровой вселенной, основанной на реалиях преподаваемой дисциплины. В качестве примера приведём ситуацию, характерную для ЛитРПГ, смоделированную на занятиях по психологии, когда четверо друзей, соответствующие по своим характеристикам четырём типам темперамента попадают через компьютерную игру «Портал» в «Псиландию» и начинают своё путешествие со знакомства с основными школами психологии, усваивают объяснительные принципы присущие различным психологическим концепциям, постигают основные закономерности психических явлений и постепенно, благодаря выполнению заданий (квестов), обрастают личностными качествами, формирующими из индивида (типажа персонажа) личность. Каждый уровень базируется на усвоении исходного учебного материала, оснащён контрольно-измерительными материалами и оценивается в баллах. Также в учебном процессе приветствуется использование отдельных заданий по темам и разделам изучаемой дисциплины, основанных на готовых текстовых произведениях в предлагаемом или родственном жанре.

2 Погружение, характерное тем, что обучающийся попадает в некую ситуацию (среду), выступая персонажем «изнутри», который по мере продвижения в игровой вселенной приобретает определённые знания, умения и навыки, отслеживая результаты этих продвижений. А также имеет возможность сравнивать свои достижения с достижениями других «персонажей» - дух соревнования. 
3 Квестовость, то есть наличие заданий разной степени (усиления) сложности, которые позволяют «студенту-персонажу» получать и совершенствовать искомые знания, умения и навыки.

4 Ролевая составляющая - обучающийся осуществляет самопознание и саморазвитие, изначально присваивая себе определённую роль в соответствии с присущими ему характеристиками (реальными или проецируемыми).

В завершение отметим, что данный подход ни в коем случае не заменит традиционное академическое обучение и носит скорее прикладной характер, дополняющий и подкрепляющий основные образовательные программы, способствуя усвоению больших объёмов информации легко и достаточно плодотворно в более короткие сроки.

$$
* * *
$$

1. Исаева, Е. Р. Новое поколение студентов: психологические особенности, учебная мотивация и трудности в процессе обучения первого курса [Электронный ресурс] / Е. Р. Исаева // Медицинская психология в России : электрон. науч. журн. - 2012. - № 4 (15). - Режим доступа: http://medpsy.ru

2. Лумпиева, Т. П. Поколение Z: Психологические особенности современных студентов [Электронный pecypc] / Т. П. Лумпиева, А. Ф. Волков. - Режим доступа: http://ea.donntu.edu.ua:8080/jspui/bitstream

3. Невский, Б. Что такое ЛитРПГ: всё о жанре / Б. Невский // Мир Фантастики. - 2014. - URL: https://www.mirf.ru/book/litrpg-vseo-chto-nuzhno-znat-o-zhanre

4. Смирнов, С. Д. Психологические факторы успешной учёбы студентов ВУЗа / С. Д. Смирнов // Факультет психологии МГУ им. М. В. Ломоносова - 2014. - URL : http://www.psy.msu.ru/science/public/smirnov/students.html

5. Товбаз, Е.Г. Основные познавательные компоненты информационно-поисковой деятельности в самостоятельной работе студентов / Е. Г Товбаз // Учёные записки КнАГТУ: Науки о человеке, обществе и культуре / Под ред. И.И. Докучаева. - Комсомольск-на-Амуре, 2011. - № I-2(5). - С. 41-45.

6. Товбаз, Е.Г. Восприятие студентами текстовой информации в зависимости от функциональной асимметрии головного мозга / Е. Г Товбаз // Наука и образование в жизни современного общества: сборник научных трудов по материалам Международной научно-практической конференции 29 ноября 2013г.: Часть 3; М-во обр. и науки РФ. Тамбов: Изд-во ТРОО «Бизнес-наука-общество», 2013. - C. $128-131$.

\section{Кобышева А.С., Ширковская Е.С. \\ Средства художественной литературы в процессе нравственно-эстетического воспитания на уроке иностранного языка}

(Россия, Ставрополь)

doi: $10.18411 /$ sr-10-08-2020-28

idsp: sciencerussia-10-08-2020-28

\section{Аннотация}

В этой статье рассматривается важность и необходимость применения средств художественной литературы в процессе нравственно- эстетического воспитания младших школьников на уроке иностранного языка. Изучаются способы нравственноэстетического воспитания на уроке иностранного языка. Итогом работы является ряд существенных предложений по проведению уроков иностранного языка с помощью средств художественной литературы. Издание рекомендовано для студентов, научных сотрудников педагогической и социальной специализации, а также для всех читателей, интересующихся вопросами нравственно- эстетического воспитания через средства художественной литературы.

Ключевые слова: нравственно-эстетическое воспитание на уроке иностранного языка, начальный этап обучения иностранному языку, средства художественной культуры, методические приемы. 